\title{
PROGRAM APLIKASI PENJUALAN BUKU ENSIKLOPEDI ISLAM BERBASIS WEB
}

\author{
Candra Wijaya, Deddy Supriadi \\ Program Studi Manajemen Informatika \\ AMIK BSI Tasikmalaya \\ Jalan Tanuwijaya No. 4 Tasikmalaya \\ digiwijaya@yahoo.co.id, deddy.dys@dbsi.ac.id
}

\begin{abstract}
Internet usable in business world as market connecting tools between buyer and seller which practice not must usage thinking about time, distance and location. Web-based application program islam ensiclopedy book store is system combine that use to support or contribute activity fluently on book store case. One of problem which happen is decrease information reached about market sale of book products so that no more people know about book store existence. This application program was builded from PHP base as server side scripting and MySQL as database server and waterfall methode as software growth process insequence trough model planning fase and solution tested. The purpose design of this application is make easy in service and give comfortely to consument also product market sale. So that with any online book e-commerce, hoped can rise service in information form to offered product and to come more customer because online market sale.
\end{abstract}

Keyword:Web-Based Application Program, Islam Ensiclopedy Book Store, Store

Abstrak - Penggunaan internet dalam dunia bisnis sebagai alat penghubung perdagangan antara penjual dan pembeli yang praktis tanpa harus memikirkan jarak, waktu dan lokasi. Program aplikasi penjualan buku ensiklopedi islam berbasis web merupakan serangkaian sistem yang digunakan untuk menunjang atau mendukung lancarnya kegiatan pada kasus penjualan buku. Salah satu permasalahan yang terjadi yaitu kurangnya penyampaian informasi mengenai pemasaran produk buku sehingga tidak banyak orang yang tahu tentang keberadaan toko buku tersebut. Program aplikasi ini dirancang berbasis web ecommerce dengan menggunakan bahasa pemograman PHP MySQL sebagai pengolahan data-data yang diperlukan dan metode waterfall sebagai proses pengembangan perangkat lunak berurutan yang melewati fase perencanaan pemodelan dan pengujian solusi. Tujuan dirancangnya aplikasi ini yaitu memudahkan dalam melayani dan memberikan kenyamanan kepada konsumen serta pemasaran produk. Sehingga dengan adanya $e$ commerce buku online, diharapkan dapat meningkatkan pelayanan dalam bentuk informasi akan produk yang ditawarkan serta mendatangkan lebih banyak pelanggan karena pemasaran secara online.

Kata Kunci : Program Aplikasi, Penjualan Buku Ensiklopedi Islam, Penjualan

\section{PENDAHULUAN}

Kebutuhan akan sistem informasi sangat penting dalam suatu instansi atau perusahaan. Manfaat sistem informasi bagi suatu instansi antara lain sebagai pendukung dan pengambilan keputusan manajerial dan pendukung operasional pekerjaan. Teknologi internet merupakan salah satu bidang yang mengalami perkembangan sangat pesat. Banyak 
sektor yang menerapkan teknologi ini, salah satunya dalam bidang perdagangan dan penyewaan dengan internet sebagai sarana utama, yaitu e-commerce pada penjualan buku ensiklopedia islam berbasis web. Implementasi e-commerce buku ensiklopedia islam dalam dunia bisnis merupakan salah satunya dari banyaknya bermunculan situs-situs penjualan online atau berbasis web. Dengan penerapan e-commerce berdampak dalam efisiensi dan efektivitas transaksi, serta dapat meningkatkan produk dan citra perusahaan tersebut.

Banyak perusahaan telah berpindah ke e-commerce dengan berbagai alasan. Perusahaan akan lebih mudah dalam melayani dan memberikan informasi kepada konsumen, disamping itu memudahkan dalam pemasaran produk sehingga lebih banyak orang yang tahu tentang keberadaan toko buku tersebut. Untuk itu dengan adanya $e$ commerce buku online diharapkan dapat meningkatkan pelayanan dalam bentuk informasi akan produk yang ditawarkan serta mendatangkan lebih banyak pelanggan karena pemasaran secara online.

\section{METODE PENELITIAN}

\section{Metode Pengembangan Perangkat Lunak}

Metode yang digunakan pada pengembangan perangkat lunak ini menggunakan model water fall (sommerville, 2007:66) yang terbagi menjadi tiga tahapan, yaitu:

1. Analisis Kebutuhan

Tahapan ini sangat menekan pada masalah pengumpulan kebutuhan pengguna pada tingkatan sistem dengan menentukan konsep sistem beserta antarmuka yang menghubungkannya dengan lingkungan sekitar. Hasilnya berupa spesifikasi sistem.

2. Perancangan Sistem dan Perangkat Lunak

Proses perancangan sistem ini difokuskan pada empat atribut, yaitu struktur data, representasi antarmuka, arsitektur perangkat lunak, dan interaksi antar objek di dalam kelas.

3. Implementasi dan Pengujian Unit Pada tahap ini, perancangan perangkat lunak direalisasikan sebagai serangkaian program atau unit program. Kemudian pengujian unit melibatkan verifikasi bahwa setiap unit program telah memenuhi spesifikasinya.

\section{Teknik pengumpulan Data}

Teknik pengumpulan data yang digunakan oleh penulis dalam melakukan pengumpulan data adalah :

1. Observasi

Menjelaskan tentang kegiatan observasi yang dilakukan meliputi : tempat atau bagian yang diobservasi.

2. Studi Pustaka

Menjelaskan tentang studi pustaka yang dilakukan untuk mendukung proses komputerisasi sistem.

\section{PEMBAHASAN}

\section{Analisa Kebutuhan}

Internet yang cakupannya program aplikasi e-commerce buku ensiklopedi islam ini digunakan untuk memudahkan penjualan dan pembelian buku jarak jauh tanpa harus 243ook243g ke 243ook buku, yaitu dengan cara pemesanan online. E-commerce buku ensiklopedi islam online ini meliputi penyampaian informasi produk-produk yang dipasarkan dan pemesanan produk dari 243ook buku tersebut. Dengan adanya program aplikasi penjualan buku ensiklopedi islam diharapkan dapat memudahkan orang-orang yang ingin berbelanja buku.

Setelah menyimak uraian diatas, penulis menemukan suatu permasalahan, yaitu kurangya promosi informasi penjualan buku kepada masyarakat luas. Alternatif pemecahan masalahnya ialah dengan membangun konsep web yang dapat memberikan keleluasaan dalam berbelanja buku dan mudah dimengerti khalayak umum. Masyarakat atau pengunjung situs web dapat membeli 
buku yang didalamnya menampilkan detail buku, bayar lewat transfer ke bank, ongkos kirim antar buku dan bukti cetak untuk tanda keabsahan transaksi pembelian buku.

\section{Perancangan Perangkat Lunak}

\section{Rancangan Antar Muka}

Rancangan antar muka pada program aplikasi penjualan buku ensiklopedia islam berbasis web sebagai berikut:

\section{Halaman Web User}

Rancangan Antar Muka Beranda (User)

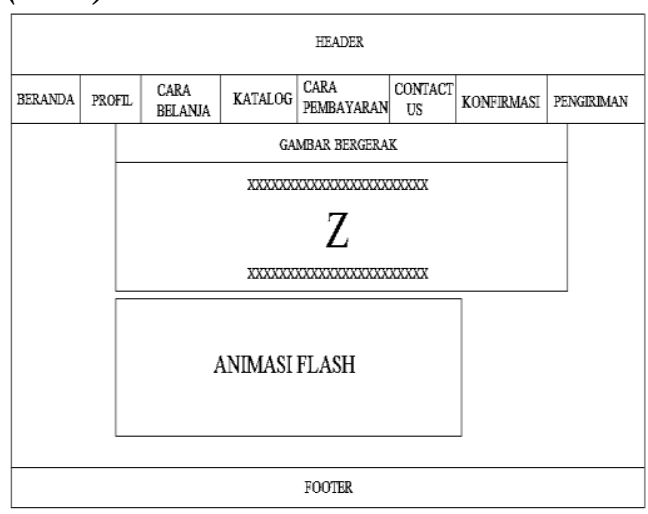

Gambar 1

Rancangan Antar Muka Beranda (User)

\section{Rancangan Antar Muka Profil (User)}

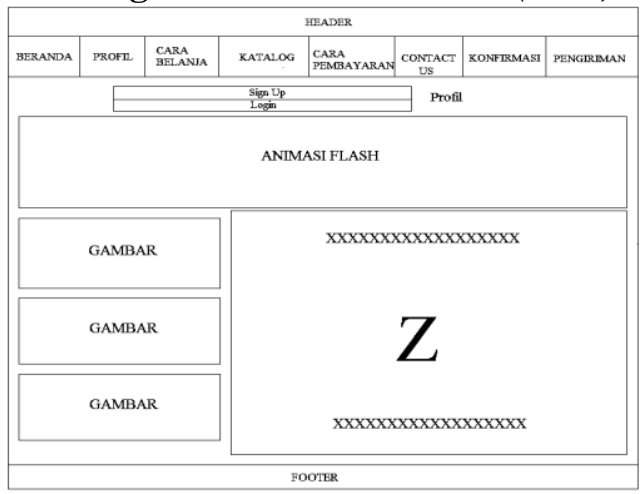

Gambar 2

Rancangan Antar Muka Profil (User)

Rancangan Antar Muka Shopping Cart (User)

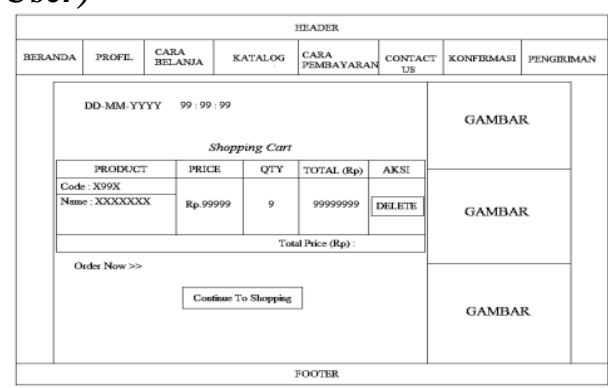

Gambar 3

Rancangan Antar Muka Shopping Cart (User)

Rancangan Antar Muka Cetak (User)

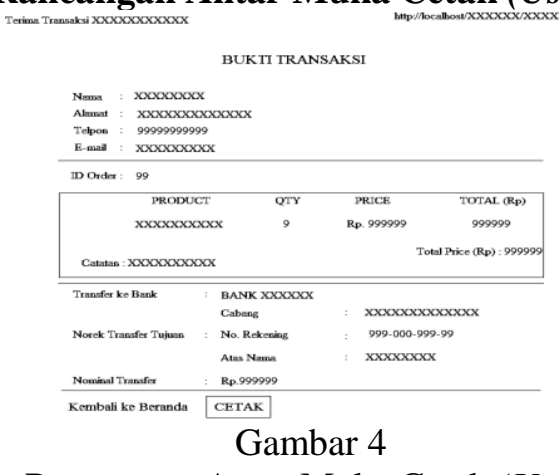

Rancangan Antar Muka Cetak (User)

\section{Halaman Web Admin}

\section{Rancangan Antar Muka Login (Admin)}

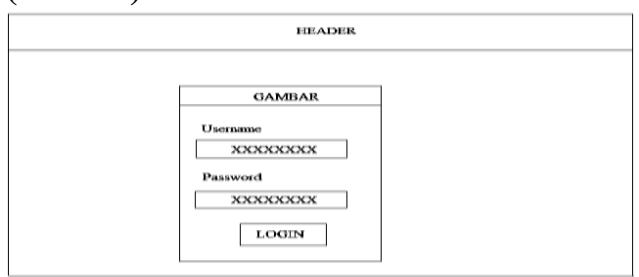

Gambar 5

Rancangan Antar Muka Login (Admin)

Rancangan Antar Muka Home
(Admin)

\begin{tabular}{|c|c|}
\hline \multirow{7}{*}{$\begin{array}{l}\text { HALAMAAN ADMIN } \\
\text { HONE } \\
\text { INPLT CAIEGORY } \\
\text { INPLT DATA BANK } \\
\text { INPLT PRODLCT } \\
\text { VIEW DATA CONTACT } \\
\text { VIEW ORDER DATA } \\
\text { CHANGE PASSWORD } \\
\text { MANAGE LSER } \\
\text { LOGOLT }\end{array}$} & SELAMAT DATANG $\{$ SESSION ID $\}$ \\
\hline & \multirow{4}{*}{$\begin{array}{l}\text { ANIMASI } \\
\text { FLASH }\end{array}$} \\
\hline & \\
\hline & \\
\hline & \\
\hline & VISIT WEBSITE KHASANAH ENSIKLIOPEDI BOOK STORE ONLRE \\
\hline & FOOIER \\
\hline \multicolumn{2}{|r|}{ Gambar 6} \\
\hline \multicolumn{2}{|c|}{$\begin{array}{c}\text { Rancangan Antar Muka Home } \\
\text { (Admin) }\end{array}$} \\
\hline
\end{tabular}




\section{Rancangan Antar Muka View Order Data (Admin)}

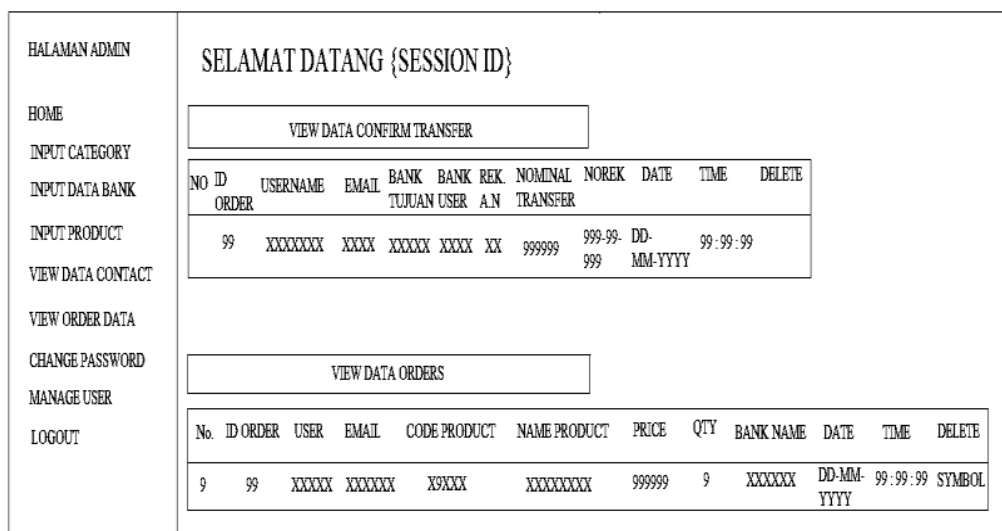

Gambar 7

Rancangan Antar Muka View Order Data (Admin)

\section{Perancangan Basis Data}

Perancangan basis data menghasilkan pemetaan tabel-tabel yang digambarkan dengan Entity Relationship Diagram (ERD), Logical Relational Structure (LRS) dan Spesifikasi File.

\section{Entity Relationship Diagram (ERD)}

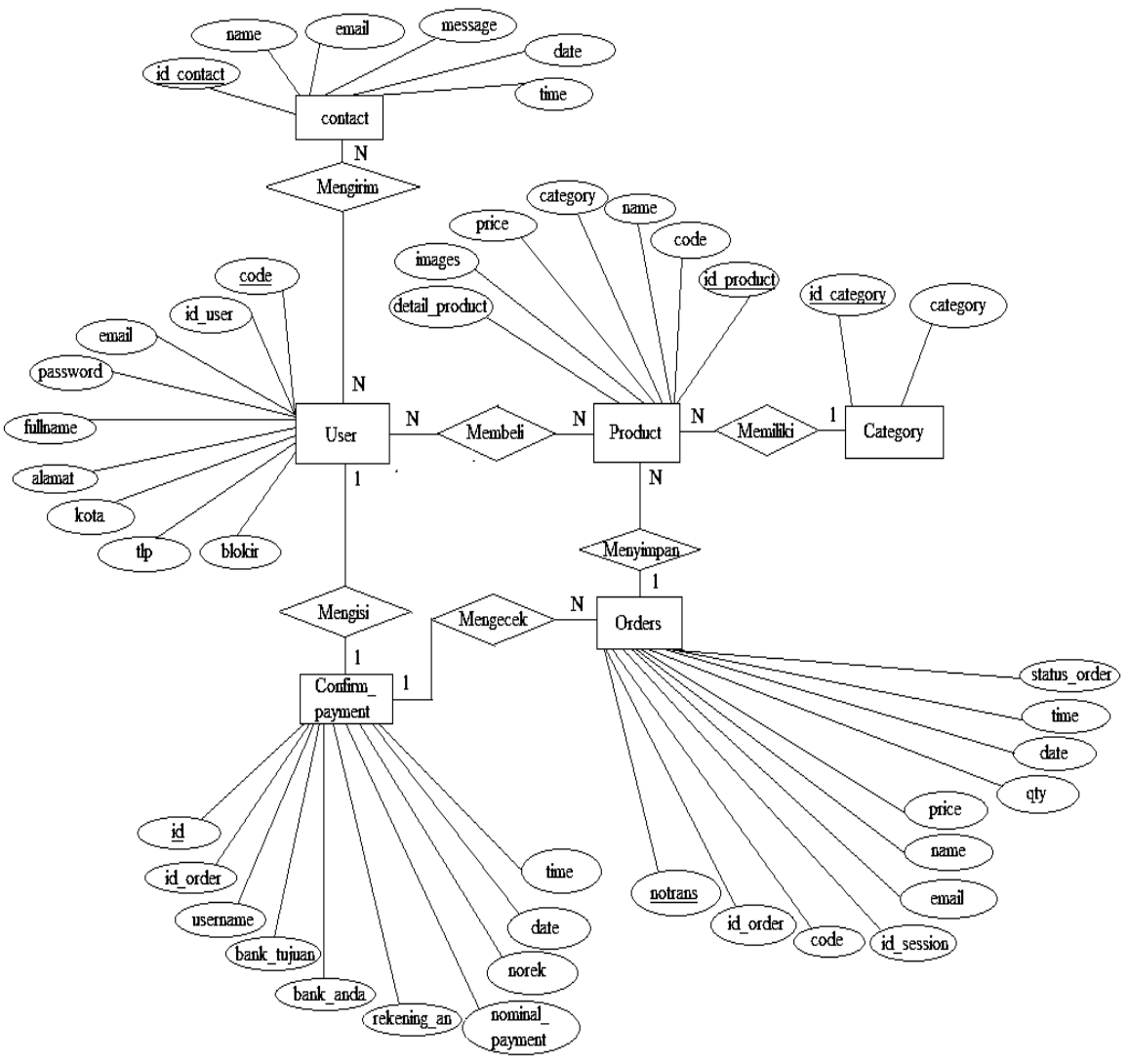

Gambar 8

Entity Relationship Diagram (ERD) 


\section{Logical Relational Structure (LRS)}

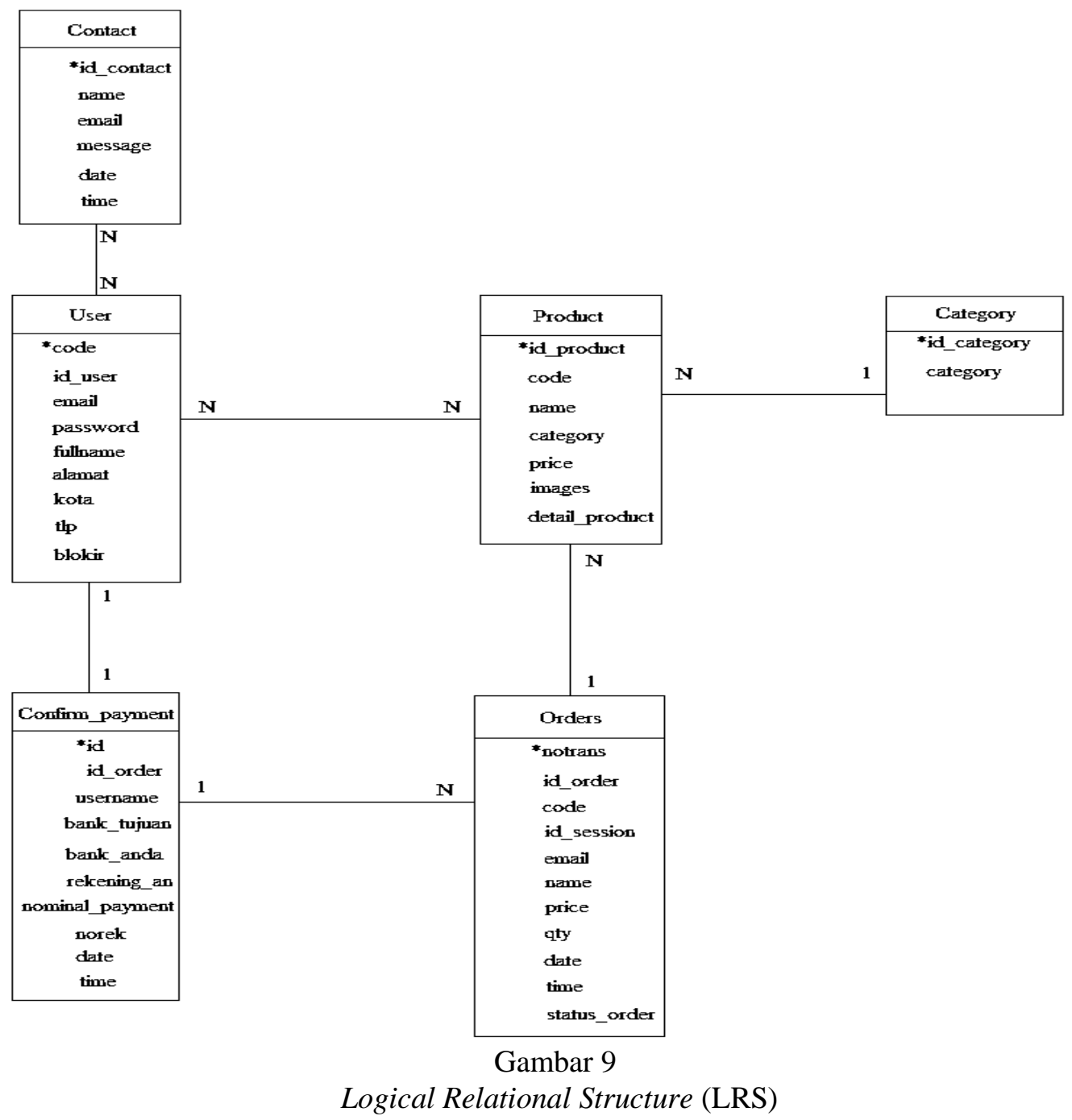

\section{Spesifikasi File}

Menjelaskan tentang file atau tabel yang terbentuk dari transformasi ERD (dan atau file-file penunjang untuk $w e b$ ). Spesifikasinya terdiri dari satu database dan sepuluh tabel, yaitu:

1. Spesifikasi File Admin

Nama File : admin

Akronim : admin

Fungsi : untuk menyimpan data admin

Tipe File : File Master

Organisasi File : Indexed

Sequential

Akses File : Random
Media : Hardisk

Panjang Record : 186

Kunci File : number

Software : MySQL

Tabel 1

Spesifikasi File Tabel admin
Elemen Tipe Panjan Ket.

\begin{tabular}{cllcl}
$\begin{array}{c}\text { No } \\
.\end{array}$ & $\begin{array}{c}\text { Elemen } \\
\text { Data }\end{array}$ & Tipe & $\begin{array}{c}\text { Panjan } \\
\mathrm{g}\end{array}$ & Ket. \\
\hline 1. & Number & Int & 1 & PK \\
\hline 2. & Id & Varchar & 20 & \\
\hline 3. & Password & Varchar & 50 & \\
\hline 4. & Email & Varchar & 50 & \\
\hline 5. & full_name & Varchar & 50 & \\
\hline 6. & Phone & Varchar & 15 & \\
\hline
\end{tabular}


2. Spesifikasi File bank

Nama File : bank

Akronim : bank

Fungsi : untuk menyimpan data bank

Tipe File : File Master

Organisasi File : Indexed

Sequential

Akses File : Random

Media : Hardisk

Panjang Record : 210

Kunci File : id_bank

Software : MySQL

Tabel 2

Spesifikasi File Tabel bank

\begin{tabular}{cllcc}
\hline No. & $\begin{array}{c}\text { Elemen } \\
\text { Data }\end{array}$ & Tipe & Panjang & Ket. \\
\hline 1. & Id bank & Int & 10 & PK \\
\hline 2. & Name & Varchar & 100 & \\
\hline 3. & Images & Varchar & 100 & \\
\hline 4. & Detail & Text & & \\
\hline
\end{tabular}

3. Spesifikasi File category

Nama File : category

Akronim : category

Fungsi : untuk menyimpan data kategori buku

Tipe File : File Master

Organisasi File : Indexed

Sequential

Akses File : Random

Media : Hardisk

Panjang Record : 111

Kunci File : id_category

Software : MySQL

Tabel 3

Spesifikasi File Tabel category

\begin{tabular}{cllcc}
\hline No. & $\begin{array}{c}\text { Elemen } \\
\text { Data }\end{array}$ & Tipe & Panjang & Ket \\
\hline 1. & Id_categ & Int & 11 & PK \\
& ory & & & \\
\hline 2. & Category & $\begin{array}{l}\text { Varcha } \\
\mathrm{r}\end{array}$ & 100 & \\
& & & &
\end{tabular}

4. Spesifikasi File confirm_payment

Nama File : confirm_payment

Akronim : confirm_payment

Fungsi : untuk menyimpan

Data konfirmasi

pembayaran

Tipe File : File Master

Organisasi File : Indexed

Sequential

Akses File : Random
Media : Hardisk

Panjang Record : 920

Kunci File : id

Software : MySQL

Tabel 4

Spesifikasi File Tabel confirm_payment

No. Elemen Data Tipe Panja $\mathrm{Ke}$

\begin{tabular}{cllcc} 
& & & $\mathrm{ng}$ & $\mathrm{t}$ \\
\hline 1. & $\underline{\text { Id }}$ & Int & 10 & $\mathrm{PK}$ \\
\hline 2. & id_order & Int & 10 & \\
\hline 3. & Username & Varchar & 100 & \\
\hline 4. & Email & Varchar & 100 & \\
\hline 5. & bank_tujuan & Varchar & 100 & \\
\hline 6. & bank_anda & Varchar & 100 & \\
\hline 7. & rekening_an & Varchar & 100 & \\
\hline 8. & nominal_pay & Varchar & 100 \\
& ment & & \\
\hline 9. & Norek & Varchar & 100 & \\
\hline 10. & Date & Varchar & 100 & \\
\hline 11. & Time & Varchar & 100 & \\
\hline
\end{tabular}

5. Spesifikasi File contact

Nama File : contact

Akronim : contact

Fungsi : untuk menyimpan data kontak

Tipe File : File Master

Organisasi File: Indexed Sequential

Akses File : Random

Media : Hardisk

Panjang Record : 70

Kunci File : id_contact

Software : MySQL

Tabel 5

Spesifikasi File Tabel contact

\begin{tabular}{cllll}
\hline $\begin{array}{c}\text { No } \\
\text { 1. }\end{array}$ & $\begin{array}{c}\text { Elemen } \\
\text { Data }\end{array}$ & Tipe & Panjang & Ket \\
\hline 2. & Name & Int & 10 & PK \\
\hline 3. & $\begin{array}{l}\text { Varch } \\
\text { ar }\end{array}$ & 30 & \\
\hline 4. & Message & Text & & \\
\hline 5. & Date & Date & & \\
\hline 6. & Time & Time & & \\
\hline
\end{tabular}

6. Spesifikasi File orders

Nama File : orders

Akronim : orders

Fungsi : untuk menyimpan data detail pesan

Tipe File : File Master

Organisasi File : Indexed

Sequential

Akses File : Random 
Media : Hardisk

Panjang Record : 597

Kunci File : notrans

Software : MySQL

Tabel 6

Spesifikasi File Tabel orders

\begin{tabular}{cllcc}
\hline No & Elemen Data & Tipe & $\begin{array}{c}\text { Panj } \\
\text { ang }\end{array}$ & Ket \\
\hline 1. & Notrans & Int & 10 & PK \\
\hline 2. & id_order & Int & 10 & \\
\hline 3. & Code & Varchar & 5 & \\
\hline 4. & id_session & Varchar & 100 & \\
\hline 5. & Email & Varchar & 100 & \\
\hline 6. & Name & Varchar & 50 & \\
\hline 7. & Price & Int & 11 & \\
\hline 8. & Qty & Varchar & 11 & \\
\hline 9. & bank_name & Varchar & 100 & \\
\hline 10. & Date & Date & & \\
\hline 11. & Time & Varchar & 100 & \\
\hline 12. & status_orde & Varchar & 100 & \\
& r & & & \\
\hline
\end{tabular}

7. Spesifikasi File product

$\begin{array}{lll}\text { Nama File } & : \text { product } \\ \text { Akronim } & : \text { product } \\ \text { Fungsi } & : \text { untuk menyimpan } \\ & \text { data produk buku } \\ \text { Tipe File } & : \text { File Master } \\ \text { Organisasi File } & : \text { Indexed } \\ \text { Sequential } & \\ \text { Akses File } & : \text { Random } \\ \text { Media } & : \text { Hardisk } \\ \text { Panjang Record } & : \text { 202 } \\ \text { Kunci File } & : \text { id_product } \\ \text { Software } & : \text { MySQL }\end{array}$

Tabel 7

Spesifikasi File Tabel product

\begin{tabular}{|c|c|c|c|c|}
\hline $\begin{array}{l}\mathrm{N} \\
\mathrm{O} .\end{array}$ & $\begin{array}{l}\text { Elemen } \\
\text { Data }\end{array}$ & Tipe & $\begin{array}{c}\text { Panjan } \\
\mathrm{g}\end{array}$ & Ket \\
\hline 1. & $\underline{\text { Id_produ }}$ & Int & 11 & $\mathrm{PK}$ \\
\hline 2. & Code & $\begin{array}{l}\text { Varcha } \\
\mathrm{r}\end{array}$ & 8 & \\
\hline 3. & Name & Varcha & 50 & \\
\hline 4. & Category & $\begin{array}{l}\text { Varcha } \\
\mathrm{r}\end{array}$ & 25 & \\
\hline 5. & Price & Int & 8 & \\
\hline 6. & Images & $\begin{array}{l}\text { Varcha } \\
\mathrm{r}\end{array}$ & 100 & \\
\hline 7. & $\begin{array}{l}\text { detail_pro } \\
\text { duct }\end{array}$ & Text & & \\
\hline
\end{tabular}

8. Spesifikasi File time_order

Nama File : time_order

Akronim : time_order

Fungsi : untuk menyimpan data waktu pesan

Tipe File : File Master

Organisasi File : Indexed

Sequential

Akses File : Random

Media : Hardisk

Panjang Record : 210

Kunci File : id_time_order

Software : MySQL

\section{Tabel 8}

Spesifikasi File Tabel time_order

\begin{tabular}{cllcc} 
No. & $\begin{array}{l}\text { Elemen } \\
\text { Data }\end{array}$ & Tipe & $\begin{array}{c}\text { Panjan } \\
\mathrm{g}\end{array}$ & Ket \\
\hline 1. & $\begin{array}{l}\text { id_time_ } \\
\text { order }\end{array}$ & Int & 10 & PK \\
\hline 2. & $\begin{array}{l}\text { Usernam } \\
\text { e }\end{array}$ & Varchar & 100 & \\
\hline 3. & $\begin{array}{l}\text { bank_na } \\
\text { me }\end{array}$ & Varchar & 100 & \\
\hline 4. & Date & Date & & \\
\hline 5. & Time & Time & & \\
\hline
\end{tabular}

9. Spesifikasi File transaction_temp

Nama File : transaction_temp

Akronim : transaction_temp

Fungsi : untuk menyimpan data pesan sementara

Tipe File : File Master

Organisasi File : Indexed

Sequential

Akses File : Random

Media : Hardisk

Panjang Record : 387

Kunci File : notrans

Software : $\overline{M y S Q L}$

Tabel 9

Spesifikasi File Tabel transaction_temp

\begin{tabular}{cllcc}
\hline $\begin{array}{c}\text { No } \\
.\end{array}$ & $\begin{array}{c}\text { Elemen } \\
\text { Data }\end{array}$ & \multicolumn{1}{c}{ Tipe } & Panjang & Ket \\
\hline 1. & Notrans & Int & 10 & PK \\
\hline 2. & Code & Varchar & 5 & \\
\hline 3. & $\begin{array}{l}\text { id_sessio } \\
\text { n }\end{array}$ & Varchar & 100 & \\
\hline 4. & Email & Varchar & 100 & \\
\hline 5. & Name & Varchar & 50 & \\
\hline 6. & Price & Int & 11 & \\
\hline 7. & Qty & Varchar & 11 & \\
\hline 8. & Images & Varchar & 100 & \\
\hline 9. & Date & Date & & \\
\hline 10. & Time & Time & & \\
\hline
\end{tabular}


10. Spesifikasi File user

Nama File : user

Akronim : user

Fungsi : untuk menyimpan data user

Tipe File : File Master

Organisasi File : Indexed

Sequential

Akses File : Random

Media : Hardisk

Panjang Record : 681

Kunci File : code

Software : MySQL

Tabel 10

Spesifikasi File Tabel user

\begin{tabular}{lllcl}
\hline $\begin{array}{l}\text { N } \\
\text { o. }\end{array}$ & $\begin{array}{c}\text { Elemen } \\
\text { Data }\end{array}$ & Tipe & $\begin{array}{c}\text { Panjan } \\
\text { g }\end{array}$ & Ket \\
\hline 1. & Code & Int & 1 & PK \\
\hline 2. & Id_user & Varchar & 20 & \\
\hline 3. & email & Varchar & 255 & \\
\hline 4. & Password & Varchar & 50 & \\
\hline 5. & Fullname & Varchar & 20 & \\
\hline 6. & Alamat & Varchar & 255 & \\
\hline 7. & Kota & Varchar & 40 & \\
\hline 8. & Tlp & Varchar & 40 & \\
\hline 9. & Blokir & Enum & Y,N & \\
\hline
\end{tabular}

11. Spesifikasi File ongkir

Nama File : ongkir

Akronim : ongkir

Fungsi : untuk menyimpan data ongkir

Tipe File : File Master

Organisasi File: Indexed Sequential

Akses File : Random

Media : Hardisk

Panjang Record : 786

Kunci File : id_ongkir

Software : MySQL

Tabel 11

Spesifikasi File Tabel ongkir

\begin{tabular}{lllcl}
\hline $\begin{array}{l}\mathrm{N} \\
\text { o. }\end{array}$ & $\begin{array}{c}\text { Elemen } \\
\text { Data }\end{array}$ & Tipe & $\begin{array}{c}\text { Panjan } \\
\mathrm{g}\end{array}$ & Ket \\
\hline 1. & Id_Ongkir & Int & 11 & PK \\
\hline 2. & Provinsi & Varchar & 255 & \\
\hline 3. & Kota_kab & Varchar & 255 & \\
\hline 4. & $\begin{array}{l}\text { Kecamata } \\
\text { n }\end{array}$ & Varchar & 255 & \\
\hline $\begin{array}{l}5 . \\
\text { Harga_on } \\
\text { gkir }\end{array}$ & Int & 10 & \\
\hline
\end{tabular}

\section{Perancangan Struktur Navigasi \\ Struktur Navigasi User (Member)}

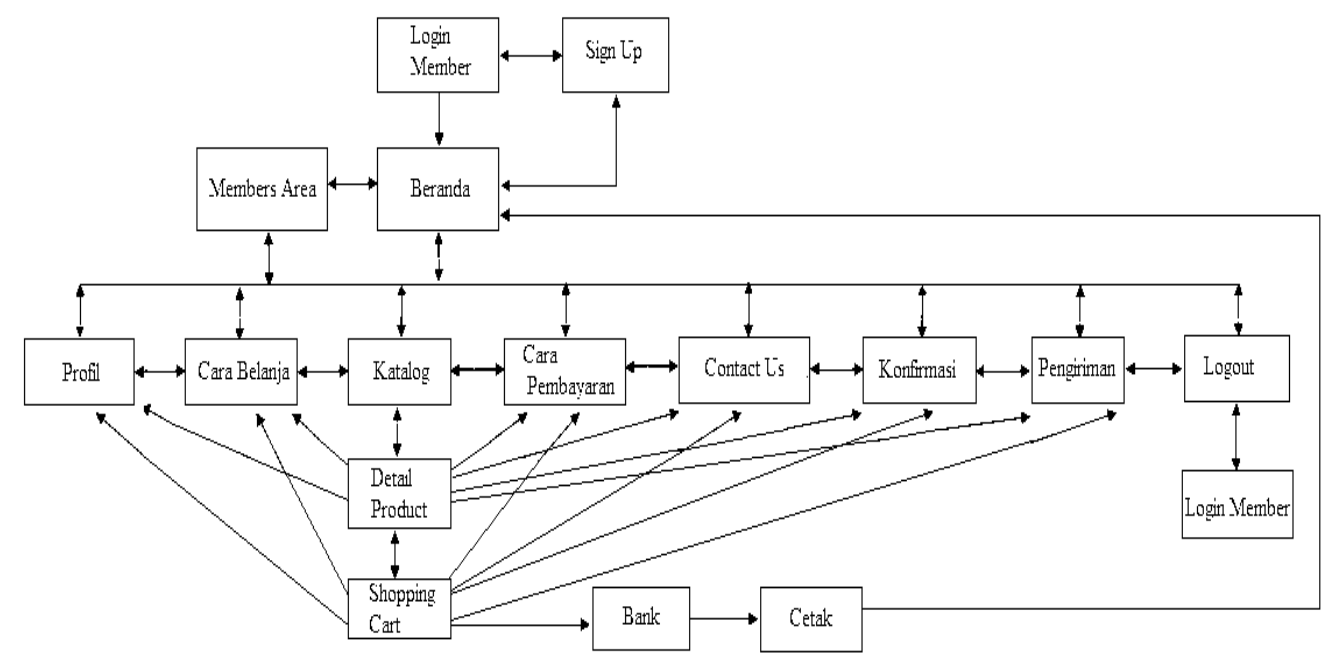

Gambar 10

Struktur Navigasi User (Member) 


\section{Struktur Navigasi Admin}

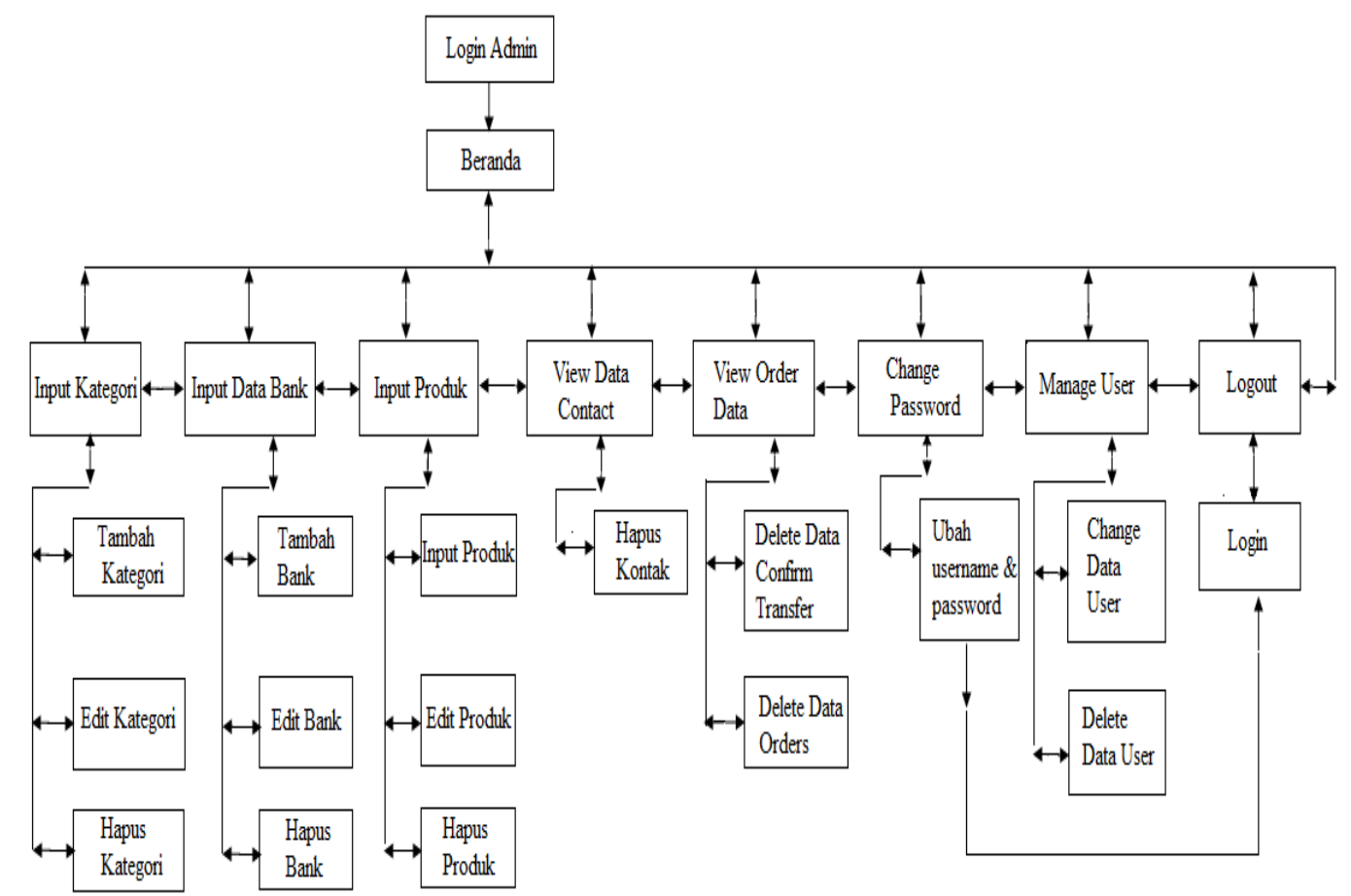

Gambar 11

Struktur Navigasi Admin

\section{Implementasi dan Pengujian Unit}

\section{Implementasi Rancangan Antar Muka}

Implementasi rancangan antar muka pada web Khasanah Ensiklopedi
Book Store Online berdasarkan hasil rancangan antar muka.

\section{Halaman Beranda (User)}

Halaman depan dari web Khasanah Ensiklopedi Book Store Online.

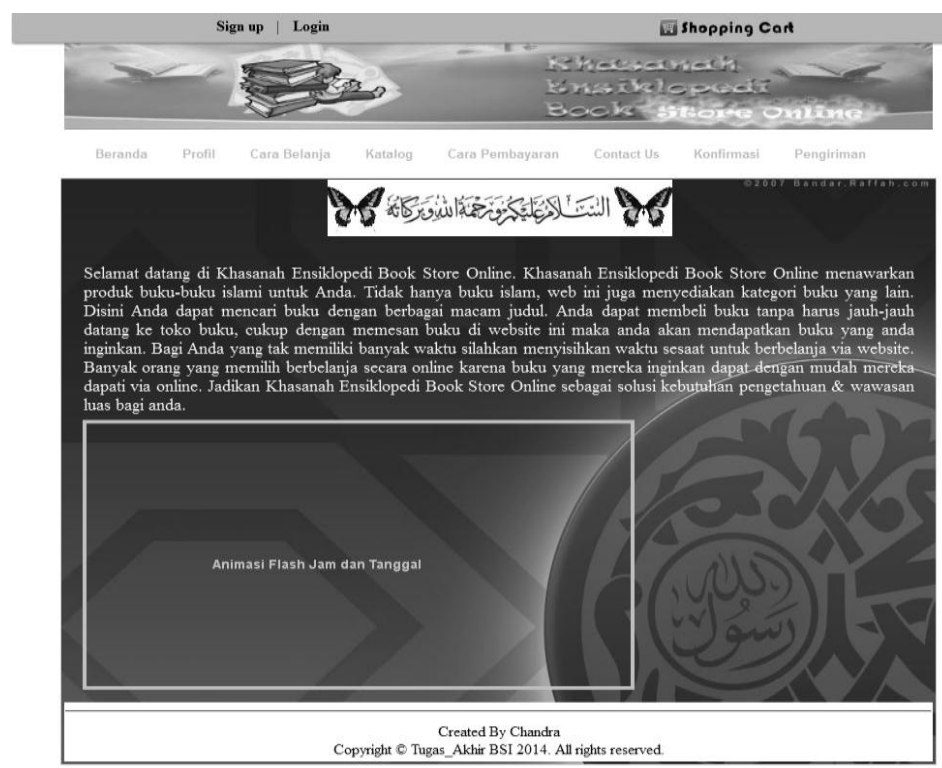

Gambar 12

Halaman Beranda (User) 


\section{Halaman Profil (User)}

Menunjukkan profil singkat dari web Khasanah Ensiklopedi Book Store Online.

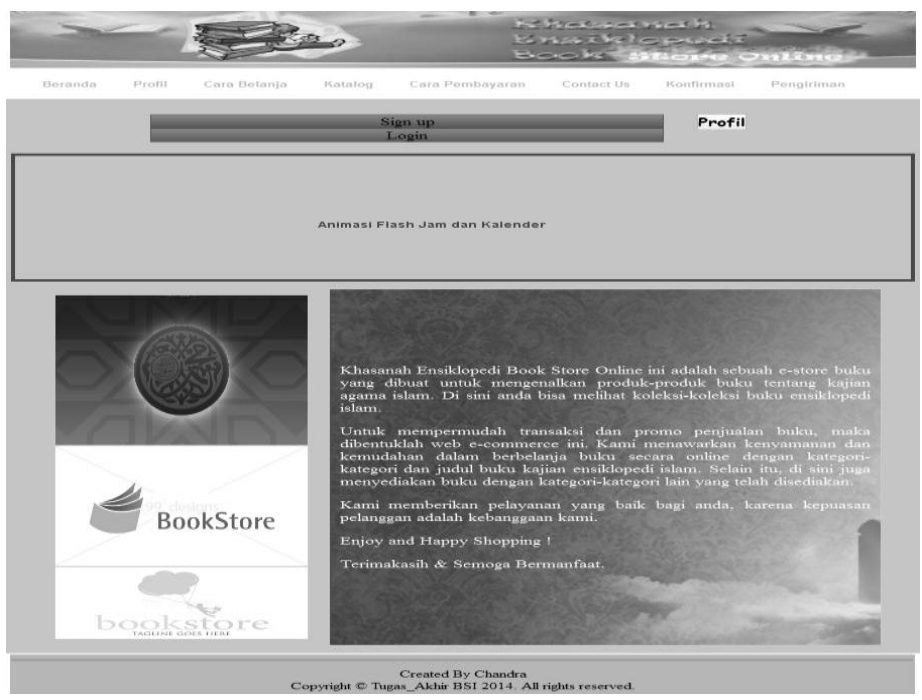

Gambar 13

Halaman Profil (User)

Halaman Shopping Cart (User)

Menampilkan rincian buku yang dibeli

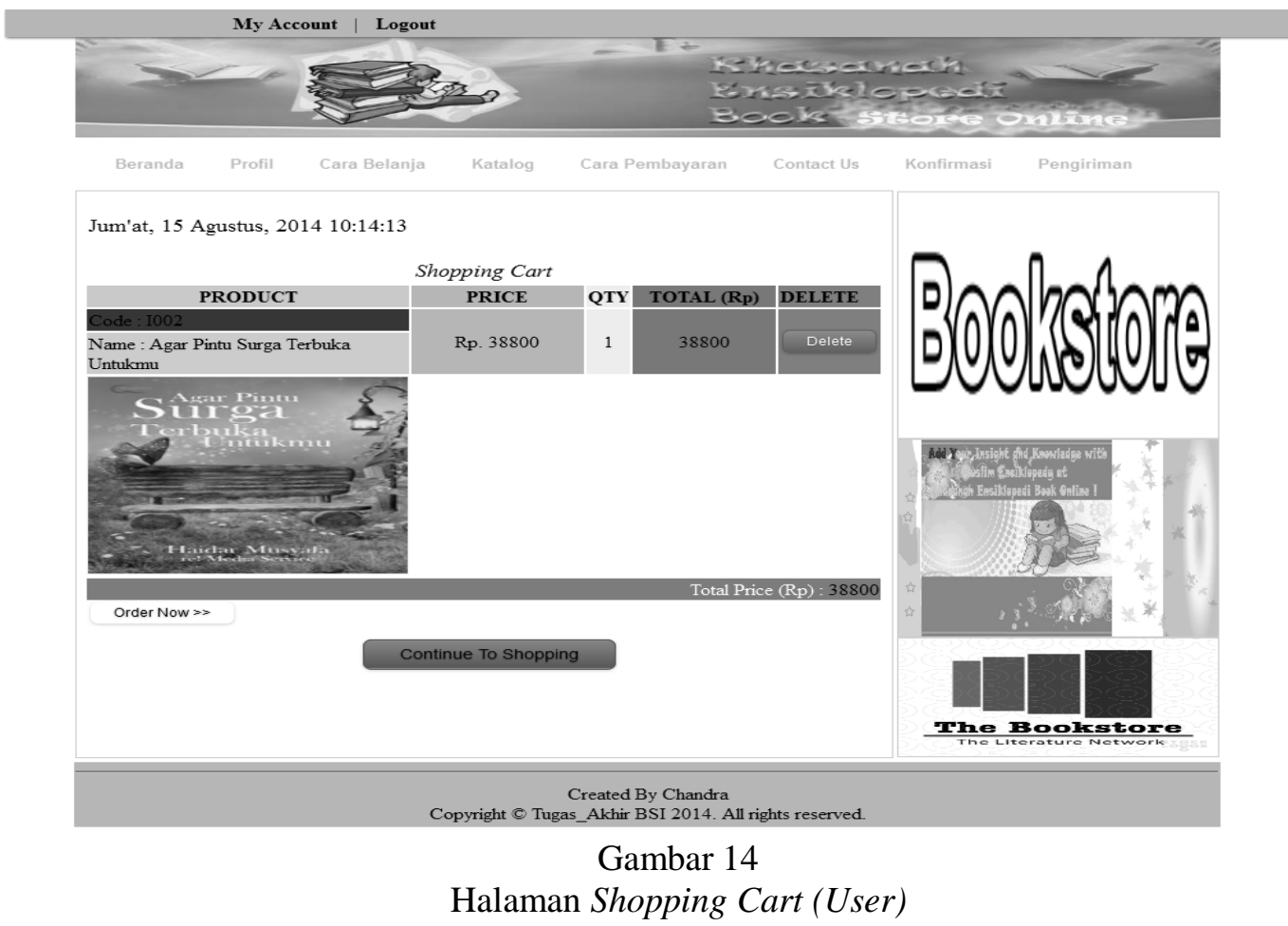




\section{Halaman Cetak (User)}

Bukti transaksi pembelian buku yang dapat di print out.

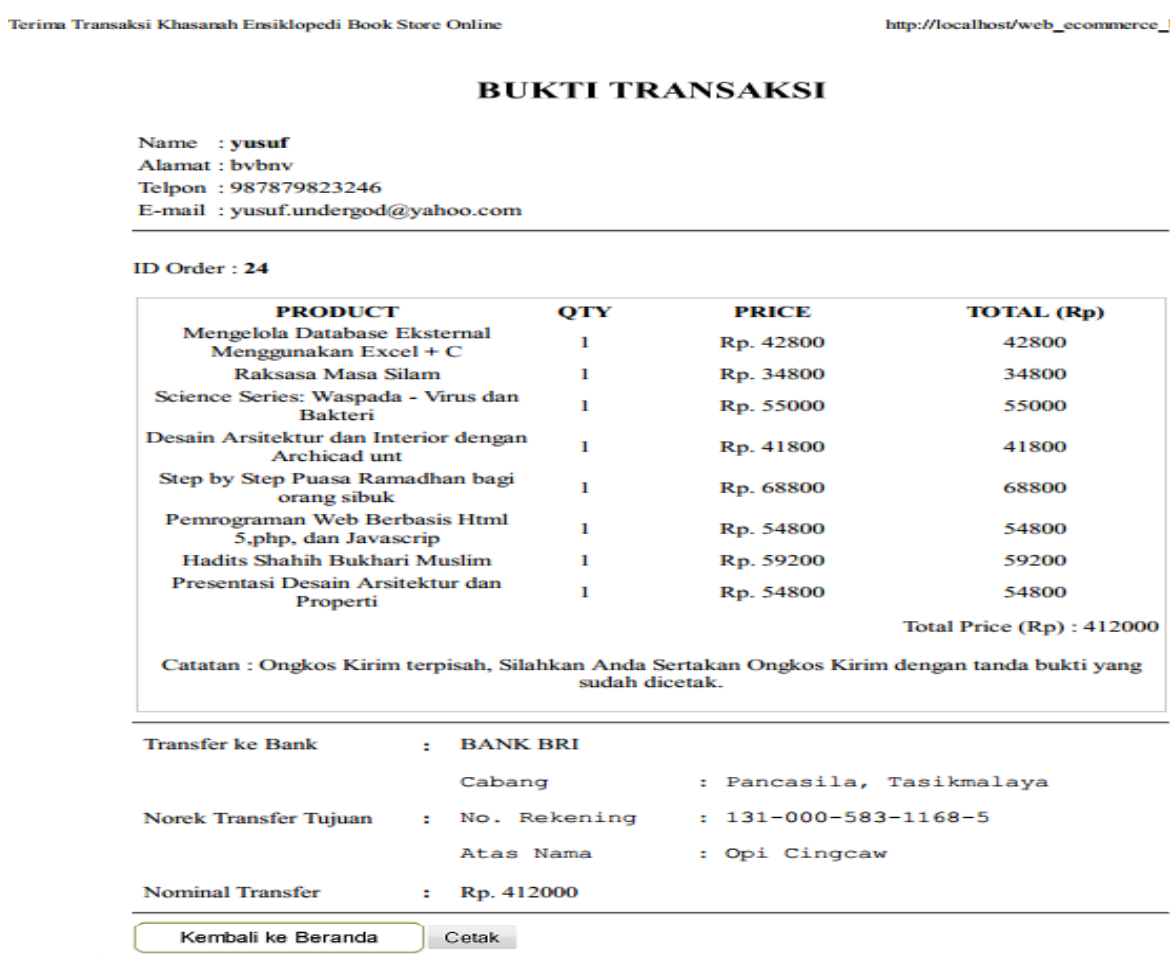

1 of 1

Gambar 15

Halaman Cetak (User)

\section{Halaman Login (Admin)}

Admin harus login terlebih dahulu sebelum memasuki halaman admin.
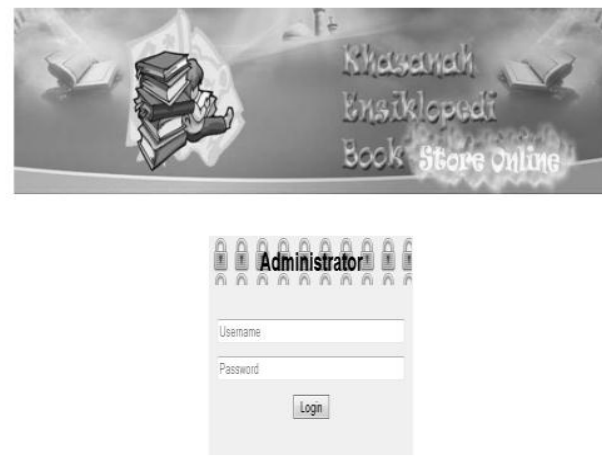

Gambar 16

Halaman Login (Admin)

\section{Halaman Home (Admin)}

Halaman awal setelah melakukan login. Terdapat navigasi ke halaman web Khasanah Ensiklopedi Book Store Online. 


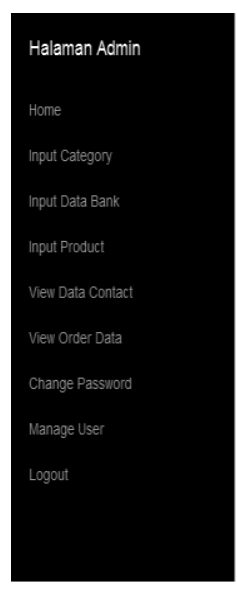

Selamat datang, nono

Gambar 17

Halaman Home (Admin)

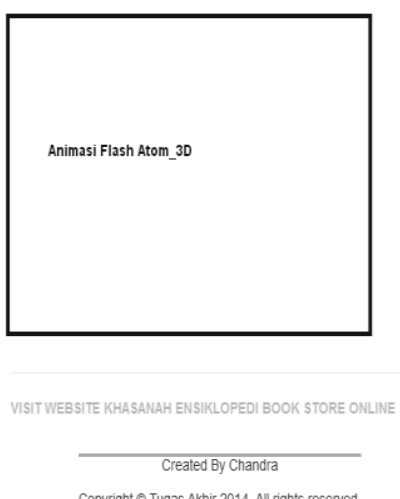

Copyright $\Theta$ Tugas Akhir 2014. All rights reserved.

\section{Halaman View Order Data (Admin)}

Admin dapat melihat data order user dan mengatur data order user.

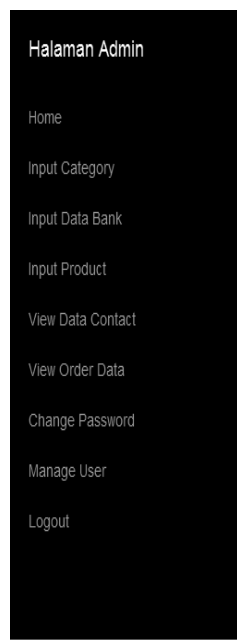

Selamat datang, gogon
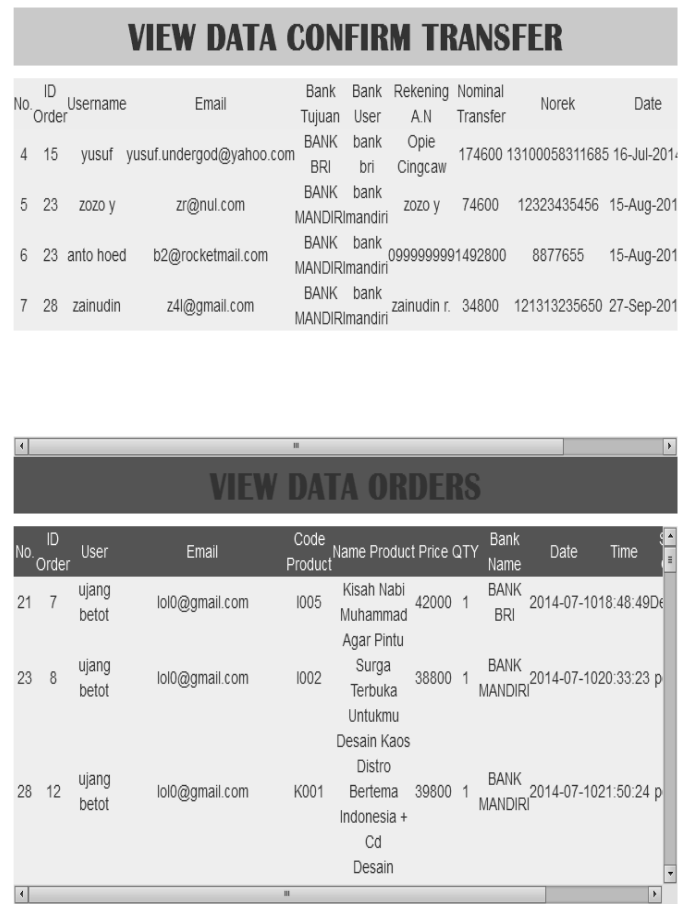

Gambar 18

Halaman View Order Data (Admin)

\section{Spesifikasi Sistem Komputer}

Berikut ini adalah spesifikasi perangkat keras dan perangkat lunak minimum yang dibutuhkan untuk mengimplementasikan website Khasanah Ensiklopedi Book Store Online.

\section{Spesifikasi Perangkat Keras}

1. Server

a. $C P U$
1) Processor Intel $®$ Atom ${ }^{\circledR}$ Inside

2) RAM DDR2 $512 \mathrm{MB}$

3) Hard Disk $1 G B$

b. Mouse

c. Keyboard

d. Monitor dengan resolusi layar minimum $1024 \times 600$ 
2. Client

e. Koneksi internet dengan kecepatan 1 Mbps.

a. $C P U$

1) Processor Intel $₫$ Atom ${ }^{\circledR}$ Inside

2) $R A M D D R 2125 \mathrm{MB}$

3) Hard Disk $100 \mathrm{mb}$

b. Mouse

c. Keyboard

d. Monitor dengan resolusi layar minimum $1024 \times 600$

e. Koneksi internet dengan kecepatan 65 Kbps.

\section{Spesifikasi Perangkat Lunak}

1. Server

a. Sistem operasi yang umum digunakan seperti: Microsoft Windows atau Linux (Ubuntu, Fedora, dll).

b. Aplikasi bundle web server seperti: Xampp, WampServer, php2triad yang terdiri dari beberapa komponen, diantaranya: Aplikasi Apache2triad, aplikasi Adobe Dreamweaver CS3, aplikasi MySQL Server v5, aplikasi phpMyAdmin v2.

c. Aplikasi Web Lihat seperti Mozilla Firefox, Opera, Safari, Internet Explorer, Google Chrome.

2. Client

a. Sistem operasi yang umum digunakan seperti: Microsoft Windows atau Linux (Ubuntu, Fedora, dll).

Aplikasi web browser seperti Mozilla Firefox, Opera, Safari, Internet Explorer, Google Chrome.

\section{Pengujian Unit}

Pengujian terhadap program yang dibuat menggunakan black box testing yang fokus terhadap proses masukan dan keluaran program.

\section{Pengujian terhadap form login user}

Tabel 12

Hasil pengujian black box testing halaman Login (User)

\begin{tabular}{|c|c|c|c|c|c|}
\hline No & $\begin{array}{l}\text { Skenario } \\
\text { Pengujian }\end{array}$ & Test case & Hasil yang diharapkan & Hasil pengujian & Kesimpulan \\
\hline 1. & $\begin{array}{l}\text { username dan } \\
\text { password tidak } \\
\text { di isi kemudian } \\
\text { klik tombol } \\
\text { login }\end{array}$ & $\begin{array}{l}\text { username : } \\
\text { (kosong) } \\
\text { password : } \\
\text { (kosong) }\end{array}$ & $\begin{array}{l}\text { Sistem akan menolak } \\
\text { akses user dan } \\
\text { menampilkan } \\
\text { "Username or Password } \\
\text { Invalid". }\end{array}$ & Sesuai harapan & Valid \\
\hline 2. & $\begin{array}{l}\text { User } \\
\text { mengetikan } \\
\text { username dan } \\
\text { password tidak } \\
\text { di isi lalu klik } \\
\text { tombol login }\end{array}$ & $\begin{array}{l}\text { username : dodo } \\
\text { password : } \\
\text { (kosong) }\end{array}$ & $\begin{array}{l}\text { Sistem akan menolak } \\
\text { akses user dan } \\
\text { menampilkan } \\
\text { "Username or Password } \\
\text { Invalid". }\end{array}$ & Sesuai harapan & Valid \\
\hline 3 & $\begin{array}{l}\text { User } \\
\text { mengetikan } \\
\text { password saja } \\
\text { dan username } \\
\text { tidak di isi } \\
\text { lalu klik } \\
\text { tombol login }\end{array}$ & $\begin{array}{l}\text { Username : } \\
\text { (kosong) } \\
\text { Password : } \\
12345\end{array}$ & $\begin{array}{l}\text { Sistem akan menolak } \\
\text { akses user dan } \\
\text { menampilkan } \\
\text { "Username or } \\
\text { Password Invalid". }\end{array}$ & $\begin{array}{l}\text { Sesuai } \\
\text { harapan }\end{array}$ & Valid \\
\hline 4. & $\begin{array}{l}\text { Mengetikkan } \\
\text { salah satu } \\
\text { kondisi salah } \\
\text { pada } \\
\text { username } \\
\text { atau } \\
\text { password }\end{array}$ & $\begin{array}{l}\text { username: } \\
\text { ripan } \\
\text { (benar) } \\
\text { Password : } \\
\text { belajar (salah) }\end{array}$ & $\begin{array}{l}\text { Sistem akan menolak } \\
\text { akses user dan } \\
\text { menampilkan } \\
\text { "Username or } \\
\text { Password Invalid". }\end{array}$ & $\begin{array}{l}\text { Sesuai } \\
\text { harapan }\end{array}$ & Valid \\
\hline
\end{tabular}




\begin{tabular}{|c|c|c|c|c|c|}
\hline & $\begin{array}{l}\text { kemudian } \\
\text { klik tombol } \\
\text { login }\end{array}$ & & & & \\
\hline 5. & $\begin{array}{l}\text { Mengetikan } \\
\text { username dan } \\
\text { password } \\
\text { dengan data } \\
\text { yang benar } \\
\text { kemudian } \\
\text { klik tombol } \\
\text { login }\end{array}$ & $\begin{array}{l}\text { username : } \\
\text { ripan } \\
\text { (benar) } \\
\text { Password : } \\
12345 \text { (benar) }\end{array}$ & $\begin{array}{l}\text { Sistem menerima } \\
\text { akses login dan } \\
\text { kemudian langsung } \\
\text { menampilkan menu } \\
\text { utama }\end{array}$ & $\begin{array}{c}\text { Sesuai } \\
\text { harapan }\end{array}$ & Valid \\
\hline
\end{tabular}

\section{Pengujian terhadap form halaman Shopping Cart User}

Tabel 13

Hasil pengujian black box testing halaman Shopping Cart User

\begin{tabular}{|c|c|c|c|c|c|}
\hline No & $\begin{array}{l}\text { Skenario } \\
\text { Pengujian }\end{array}$ & $\begin{array}{l}\text { Test } \\
\text { case }\end{array}$ & Hasil yang diharapkan & $\begin{array}{c}\text { Hasil } \\
\text { pengujian }\end{array}$ & Kesimpulan \\
\hline 1. & $\begin{array}{l}\text { User } \\
\text { membatalk } \\
\text { an pesanan }\end{array}$ & $\begin{array}{l}\text { Klik } \\
\text { tombol } \\
\text { remove }\end{array}$ & $\begin{array}{l}\text { Sistem menerima } \\
\text { perintah dan } \\
\text { menghapus pesanan, } \\
\text { tampil "Shopping Cart } \\
\text { is Empty" }\end{array}$ & $\begin{array}{l}\text { Sesuai } \\
\text { harapan }\end{array}$ & Valid \\
\hline 2. & $\begin{array}{l}\text { User } \\
\text { melanjutka } \\
\text { n belanja } \\
\text { buku }\end{array}$ & $\begin{array}{l}\text { Klik } \\
\text { tombol } \\
\text { Contin } \\
\text { ue } \\
\text { Shoppi } \\
\text { ng }\end{array}$ & $\begin{array}{l}\text { Sistem mengakses ke } \\
\text { halaman semua buku }\end{array}$ & $\begin{array}{l}\text { Sesuai } \\
\text { harapan }\end{array}$ & Valid \\
\hline 3. & $\begin{array}{l}\text { User } \\
\text { membeli } \\
\text { buku }\end{array}$ & $\begin{array}{l}\text { Klik } \\
\text { tombol } \\
\text { Order } \\
\text { Now }\end{array}$ & $\begin{array}{l}\text { Sistem mengakses ke } \\
\text { halaman bank }\end{array}$ & $\begin{array}{l}\text { Sesuai } \\
\text { harapan }\end{array}$ & Valid \\
\hline 4. & $\begin{array}{l}\text { User } \\
\text { memilih } \\
\text { bank dan } \\
\text { melanjutka } \\
\text { n ke } \\
\text { halaman } \\
\text { berikutnya }\end{array}$ & $\begin{array}{l}\text { Pilih } \\
\text { bank, } \\
\text { klik } \\
\text { tombol } \\
\text { process }\end{array}$ & $\begin{array}{l}\text { Sistem mengakses } \\
\text { halaman cetak order }\end{array}$ & $\begin{array}{l}\text { Sesuai } \\
\text { harapan }\end{array}$ & Valid \\
\hline 5. & $\begin{array}{l}\text { User } \\
\text { menyimpan } \\
\text { bukti } \\
\text { transaksi }\end{array}$ & $\begin{array}{l}\text { Klik } \\
\text { tombol } \\
\text { cetak }\end{array}$ & $\begin{array}{l}\text { Sistem menerima } \\
\text { perintah dan } \\
\text { menampilkan tanda } \\
\text { bukti transaksi beli }\end{array}$ & $\begin{array}{l}\text { Sesuai } \\
\text { harapan }\end{array}$ & Valid \\
\hline
\end{tabular}

Pengujian terhadap form halaman login admin

Tabel 15

Hasil pengujian black box testing halaman Login Admin

\begin{tabular}{cccccc}
\hline No & $\begin{array}{l}\text { Skenario } \\
\text { Pengujian }\end{array}$ & Test case & $\begin{array}{c}\text { Hasil yang } \\
\text { diharapkan }\end{array}$ & $\begin{array}{c}\text { Hasil } \\
\text { pengujian }\end{array}$ & Kesimpulan \\
\hline 1. & Username & User name & Sistem akan & Sesuai & Valid \\
\hline
\end{tabular}




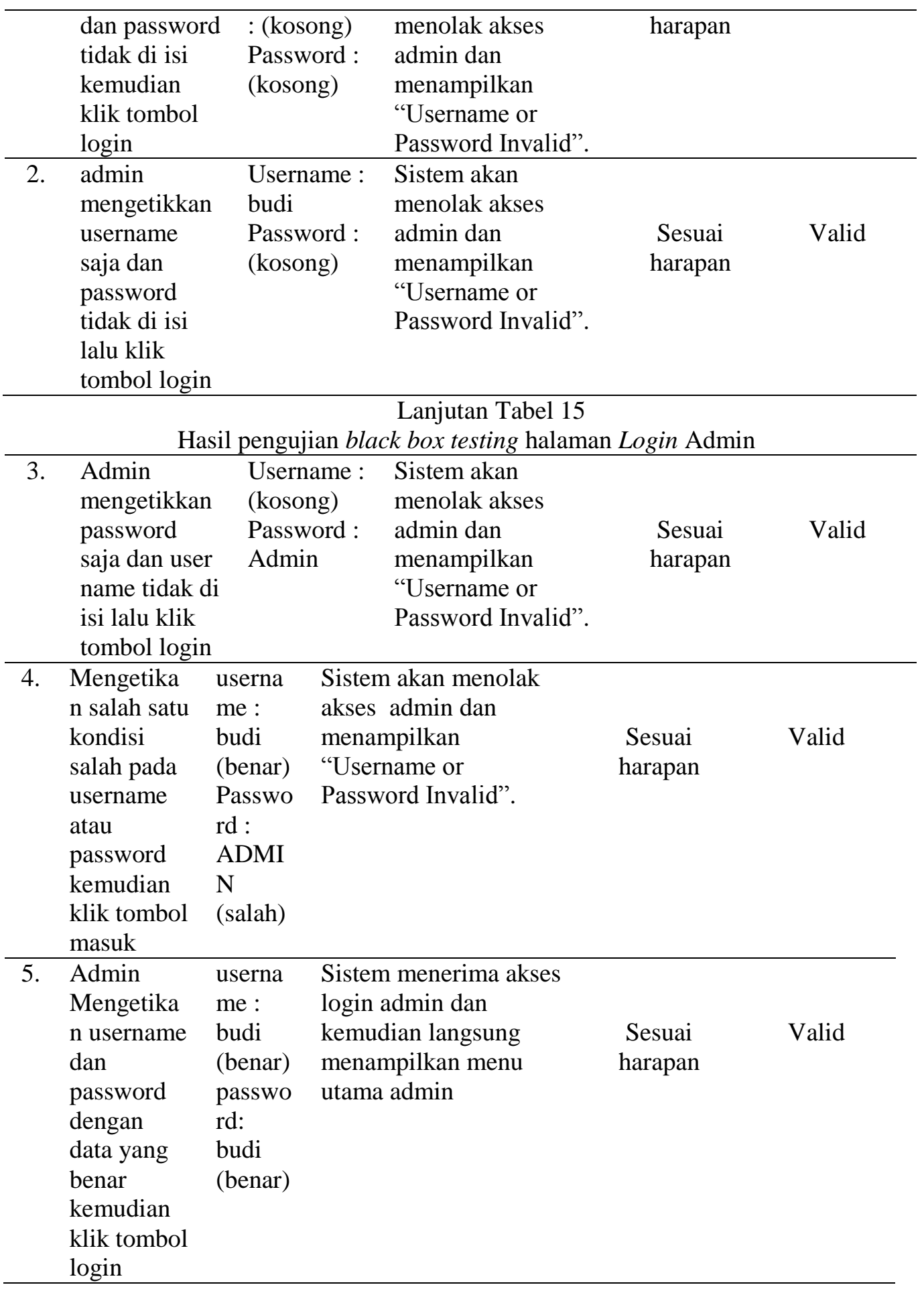

\section{PENUTUP}

\section{Kesimpulan}

Berdasarkan

pembahasan sebelumnya, maka dapat diambil kesimpulan sebagai berikut:
1. Telah dihasilkan aplikasi e-commerce penjualan buku, dimana sistem tersebut dibuat berbasis web.

2. Aplikasi e-commerce penjualan buku digunakan untuk pengelolaan semua data yang berkaitan dengan produk yang ditawarkan, pengelolaan data, 
data pesanan yang membutuhkan pengelolaan informasi berkaitan dengan pesanan buku, serta bukti cetak sebagai tanda keabsahan transaksi.

\section{Saran}

Saran yang dapat penulis sampaikan dari pembuatan e-commerce penjualan buku ini diantaranya yaitu:

1. Untuk dapat lebih dikembangkan harus ditambahkan halaman pencarian buku, baik berdasarkan judul, penulis, nama penerbit dan nama kategorinya sehingga memudahkan dalam menemukan buku yang diinginkan.

2. Aplikasi e-commerce penjualan buku ini memerlukan layanan seperti visa, sehingga memungkinkan pembayaran yang aman, nyaman dalam transaksi online pada program aplikasi khasanah ensiklopedi book store online.

3. Penambahan halaman request buku jika pengunjung (member) menginginkan buku yang tidak tersedia pada web ini.

4. Penambahan admin yang bisa dilakukan dalam halaman admin tanpa harus melalui database.

\section{REFERENSI}

Anne Ahira. 2014. Pengertian Homepage adalah -Mengenal Pengertian Homepage. Diambil dari: http://www.anneahira.com/pengerti an-homepage-adalah.htm (04 Juli 2014).

Bowo, Eri. cPanel : Panduan Wajib Untuk Web Master. Jakarta: Jasakom.

Brainly. 2014. Logical Record Structure. Diambil dari: http://brainly.co.id/tugas/263826 (04 Juli 2014).

DesainWeb. 2013. Pengertian Website Apa Itu Website?. Diambil dari: http://desainweb.com/site/pengertia n-website-apa-itu-website/ (03 Juli 2014).

Hidayatullah, M. Nur. 2013. Penerapan Metodologi Waterfall dalam Pengembangan Sistem Informasi Akademik Universitas Negeri Surabaya. Diambil dari: http://jenengkudayat.mhs.narotama.ac.id/files/201 3/10/makalah-analisis-SSI.pdf (04 Juli 2014).

Kompasiana. 2013. Pengertian dan Fungsi HTTP. Diambil dari: http://teknologi.kompasiana.com/in ternet/2013/01/31/pengertian-danfungsi-http-530151.html (04 Juli 2014).

Mayoka, R. 2011. Adobe Photoshop CS3. Diambil dari: http://repository.usu.ac.id/bitstream /123456789/27980/3/Chapter/20II. pdf (04 Juli 2014).

Mulhim, Imam. 2013. Aplikasi TOKO BANGUNAN Online dengan PHP \& MySQL. Jakarta: PT. Elex Media Komputindo.

Oktavian, Diar Puji. 2013. Komputer Pedia membuat website powerfull menggunakan PHP. Jakarta: PT. Elex Media Komputindo.

Pengertian Ahli. 2013. Pengertian Sistem Menurut Para Ahli. Diambil dari: http://www.pengertianahli.com/201 3/08/pengertian-sistem-menurutpara-ahli.html (04 Juli 2014).

Putri, MS. 2011. Apache2Triad. Diambil dari:

http://repository.usu.ac.id/bitstream /123456789/29098/4/Chapter/2011 .pdf (04 Juli 2014).

Rahman, Su. 2013. Panduan Web Programming pemula. Semarang: Erlangga. 
Santiw. 2013. Sistem Informasi. Diambil dari:

http://santiw.staff.gunadarma.ac.id/ Downloads/files/7691/Pengantar_S istem_Informasi.doc (03 Juli 2014).

Simarmata, Janner. 2010. Rekayasa Web. Yogyakarta: C.V Andi Offset.

Supardi, Yuniar. 2013. Koleksi Program Tugas Akhir dan Skripsi dengan FoxPro 9. Jakarta: PT. Elex Media Komputindo.

Sutaji, Deni. 2011. Sistem Inventory MINI MARKET dengan PHP \& JQUERY. Jakarta: Gramedia.

Sya'ban, Wahyu. 2010. Build Your Blogger XML Template.

Yogyakarta: C.V Andi Offset.

Termasmedia. 2012. Pengertian Internet. Diambil dari:

http://www.termasmedia.com/65pengertian/71-pengertianinternet.html (03 Juli 2014).

Unikom. 2012. Adobe Dreamweaver CS3. Diambil dari: http://elib.unikom.ac.id/download. php?id=83127 (04 Juli 2014).

Wildan. 2013. White Box Testing \& Black Box Testing. Diambil dari:

http://bangwildan.web.id/berita-176white-box-testing--black-boxtesting.html (04 Juli 2014).

Willis. 2009. Sebenarnya, Apa Arti dari Informasi Itu ?!. Diambil dari:http://willis.comze.com/penger tian_informasi.html (04 Juli 2014). 